\title{
Evolutionary Origin of Religions and Religious Evolution: Religious Neurosociology
}

\author{
Dingyu Chung \\ Utica, Michigan, USA \\ Email: dy_chung@yahoo.com
}

How to cite this paper: Chung, D. (2018) Evolutionary Origin of Religions and Religious Evolution: Religious Neurosociology. Journal of Behavioral and Brain Science, 8 , 485-511.

https://doi.org/10.4236/jbbs.2018.89030

Received: July 28, 2018

Accepted: September 1, 2018

Published: September 4, 2018

Copyright $\odot 2018$ by author and Scientific Research Publishing Inc. This work is licensed under the Creative Commons Attribution International License (CC BY 4.0).

http://creativecommons.org/licenses/by/4.0/

\begin{abstract}
The paper proposes that the evolutionary origin of religions is based on theory of mind as the product of interdependent division of labor between the forest specialist group (women and small children) and the woodland specialist group (men) in early hominins who lived in the mixed forest-woodland habitat. To complement each other's work without interfering each other's work, one specialist group had to recognize (imagine) that the other specialist group existed to think for themselves and to do different works. The result was theory of mind which is to recognize (imagine) that the others exist to think for themselves. (The forest-woodland groups became the hunter-gatherer groups for the Homo species in the savanna habitat.) Under existential pressure, hominins invented imaginary specialists as imaginary agents who existed to think for themselves and to do different works in imaginary division of labor to enhance survival chance. The result was religion with imaginary behaviors. Therefore, religion is defined as a set of beliefs and behaviors based on theory of mind that produces a shared imagination to enhance survival chance under existential pressure. This paper proposes that the religious evolution consists of the premodern imaginative religion for local society habitat starting from bipedalism, the modern rational imaginative religion for regional society habitat starting from the Axial Age, and the postmodern diverse rational imaginative religion for global society habitat starting from the Information Revolution. In conclusion, the religious brain is the imaginative brain, and the religious social behaviors are imaginary social behaviors. The religious evolution is the evolution of human imagination to enhance survival chance under existential pressure, such as the religious reinforcement of social bonds to enhance the survival chance of social group and the religious relief of stress and anxiety to enhance the survival chance of individuals.
\end{abstract}

\section{Keywords}

Religious Neurosociology, Evolutionary Origin of Religions, Religious 
Evolution, Neuroscience, Theory of Mind, Mental Immune System, Ingroup, Social Religion, Immune Religion, Premodern Religion, Modern Religion, Postmodern Religion

\section{Introduction}

Religion is broadly defined as a set of beliefs and behaviors based on a shared worldview that separates the sacred, or supernatural, from the profane [1]. Sacred, supernatural, and profane are basically religious terms. Instead of explaining religion by religion, this paper proposes that religion is explained by religious neurosociology [2] as the combination of neuroscience to study the religious brain and sociology to study religious social behaviors. The first step in religious neurosociology is to find the evolutionary origin of religions. One of the theories for evolutionary origin of religions is based on the neocortex size which correlates with the level of social complexity. As a result, the human neocortex is large enough to process complex social phenomena such as religion [3]. However, the recent discovery of the ritual burial practiced by Homo naledi with the brain size about half of the size of the current human brain shows that the small-sized hominin brain could have religious behaviors [4].

Another theory of evolutionary origin of religions is based on theory of mind. According to Kapogiannis and Deshpande in the functional MRI study of the brains of both self-declared religious and non-religious individuals, individuals with stronger theory of mind activity were found to be more religious [5]. Thinking about God activates brain regions associated with theory of mind [6]. Autism with the deficits in theory of mind is linked to lower belief in God [7]. Theory of mind is to recognize (imagine) that the others exist to think for themselves. Typically, religious behaviors involve recognizing (imaging) that imaginary agents exist to think for themselves, so religious behaviors involve theory of mind.

Theory of mind is to recognize (imagine) that the others exist to think for themselves, so it is closely related to imagination. Imagination is the mental ability to produce images, thoughts, and feelings independent of immediate input perceptions such as vision and hearing. Autistic individuals with problems in imaginative capacities and pretend plays are incapable of theory of mind [8] [9] [10]. Robust religion is unique to humans, because robust theory of mind is unique to humans [11]. According to Maurice Bloch [12], the first widespread human religion was derived from the imagination to produce imaginary female figurines and imaginary cave paintings to helps them to survive under existential pressure at the time of the Upper Paleolithic Revolution [13].

As shown in the previous paper [14], theory of mind was not evolved originally to accommodate religious behaviors. Theory of mind was evolved originally to accommodate interdependent division of labor between the forest specialist group (women and children) and the woodland specialist group (men) in early 
hominins who lived the mixed forest-woodland habitat. To complement each other's work without interfering each other's work, one specialist group had to recognize (imagine) that the other specialist group existed to think for themselves and to do different works. The result was theory of mind which is to recognize (imagine) that the others exist to think for themselves. (The forest-woodland groups became the hunter-gatherer groups for the Homo species in the savanna habitat.) Under normal condition, specialists in division of labor were real. Since theory of mind is closely related to imagination, humans under existential pressure invented imaginary specialists as imaginary agents who existed to think for themselves and to do different work in imaginary division of labor to enhance survival chance. Therefore, religion is defined as a set of beliefs and behaviors based on theory of mind that produces a shared imagination to enhance survival chance under existential pressure, such as the religious reinforcement of social bonds to enhance the survival chance of social group [15] and the religious relief of stress and anxiety to enhance the survival chance of individuals [16]. Existential pressure that reduces survival chance is analogous to evolutionary pressure that reduces reproductive success. Religious imagination that enhances survival chance under existential pressure is analogous to new biological trait that enhances reproductive success under evolutionary pressure.

The imaginary behaviors derived from imagination are considered religiously as the spiritual behaviors which are supernatural and sacred separated from the natural behaviors which are profane. Natural in this paper is defined as un-imaginary. As a result, human behaviors consist of natural behaviors and imaginary behaviors, corresponding religiously to secular behaviors and sacred behaviors, respectively. Natural human behaviors are basically the great ape behaviors which do not have robust (explicit) theory of mind [17]. The imaginary behaviors in established religion are adaptive to overcome existential pressure, so they are not pathological.

This paper proposes that religious neurosociology consists of religion type, religion formation, and religion learning. Religion types include social religion to maintain attachment to imaginary ingroup [15] [18] and immune religion to maintain the imaginary mental immune system against adversities [14]. In religion formation, under imagination, existential pressure and ontogenetic ritualization [19] [20], the natural (un-imaginary) instinctive attachment to ingroup turns into the attachment to imaginary ingroup for social religion, and the natural instinctive mental immune system against adversities turns into the imaginary mental immune system for immune religion. Religion learning is through the imagination derived from mental synthesis [21].

For religious evolution, different religions have been evolved in different religious habitats. This paper proposes that the religious evolution consists of the premodern imaginative religion for local society habitat starting from bipedalism, the modern rational imaginative religion for regional society habitat starting from the Axial Age, and the postmodern diverse rational imaginative religion for global society habitat starting from the Information Revolution [22]. 
The paper will discuss the evolutionary origin of religions in Section 2, the religious neurosociology in Section 3, the premodern religious evolution in Section 4 , the modern religious evolution in Section 5, and the postmodern religious evolution in Section 6.

\section{The Evolutionary Origin of Religions}

This paper proposes that the evolutionary origin of religions is based on theory of mind. As described in the previous paper [14], theory of mind was derived from division of labor based on bipedalism and the mixed habitat at the beginning of the hominin evolution. Early hominins were evolved in the mixed habitat of dense forest and open woodland [23], where Ardi (Ardipithecus ramidus) [24] (4.4 million year ago). Woodland allowed increasingly amount of food from bushes and low branches, which could be seen and reached from the ground. According to the observation [25] in Africa, chimpanzees today move on two legs most often when feeding on the ground from bushes and low branches. The result was bipedalism. The primitive feet from the original bipedalism were still suitable for climbing trees, and not suitable to run fast on the ground especially for pregnant hominins, older hominins, and small children. As a result, in the mixed habitat of grassy woodland with patches of denser forest of tall trees, pregnant hominins and older hominins took care of children, and searched foods in the forest area of tall trees as safe home where they could quickly escape to tall trees by climbing, whereas other people explored grassy woodland area to search for foods that could not be found in the forest. All of them shared foods [26] to form division of labor. To complement each other's work without interfering each other's work, one specialist group had to recognize (imagine) that the other specialist group existed to think for themselves and to do different works. The result was theory of mind which is to recognize (imagine) that the others exist to think for themselves. (The forest-woodland groups became the hunter-gatherer groups for the Homo species in the savanna habitat.) Under normal condition, specialists in division of labor were real. Since theory of mind is closely related to imagination, hominins under existential pressure invented imaginary specialists as imaginary agents who could think for themselves, and could do different work in imaginary division of labor to enhance survival chance. The result was religion with imaginary behaviors. Therefore, religion is defined as a set of beliefs and behaviors based on theory of mind that produces a shared imagination to enhance survival chance under existential pressure, such as the religious reinforcement of social bonds to enhance the survival chance of social group [15] and the religious relief of stress and anxiety to enhance the survival chance of individuals [16]. The evolution for the origin of religion is shown in Figure 1.

As described in the previous paper [27], the human biological evolution is the four-step human biological evolution. Different steps have different capacities of the feet (climbing tree and walking), different habitats, different divisions of 


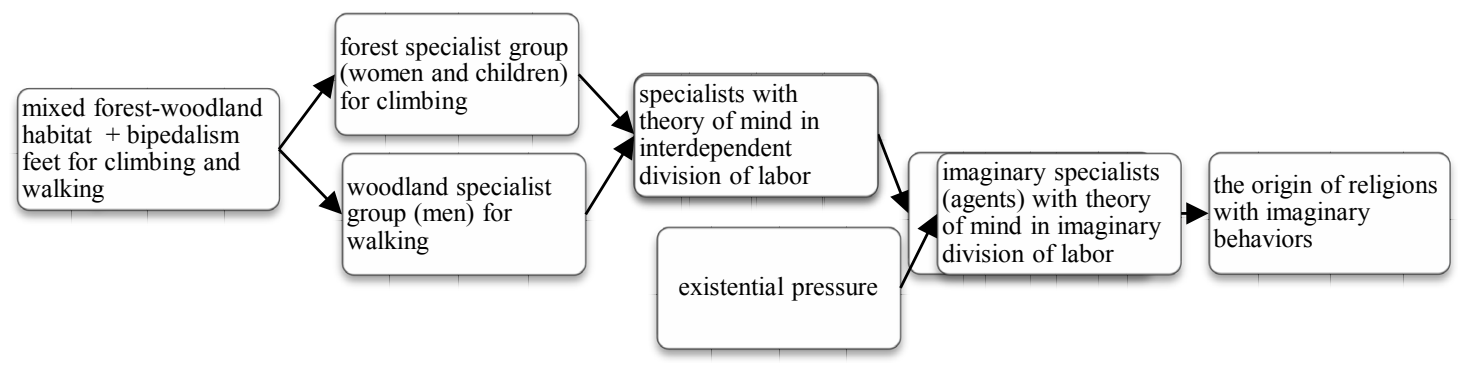

Figure 1. The Evolutionary Origin of Religions: Early hominins lived in the mixed forest-woodland habitat with the feet for both climbing trees and walking which forced early hominins to divide existentially into the forest specialist group (women and children) and the woodland specialist group (men). The existential cooperation between the two groups resulted in specialists with theory of mind in interdependent division of labor. Under existential pressure, hominins invented imaginary specialists as imaginary agents with theory of mind in imaginary division of labor. The origin of religions with imaginary behaviors emerged.

labor in terms of specialist groups, and different language capabilities. The human biological evolution includes the early hominins with the feet for climbing and walking and with the forest-woodland groups in the mixed forest-woodland habitat, the early Homos with the feet for climbing and walking and with the woodland-savanna groups in the mixed woodland-savanna habitat, the middle Homos with the feet for walking and with the hunter-gatherer groups in the savanna habitat, and the late Homos with the feet for walking and the hunter-gatherer groups in the savanna habitat. The human biological evolution is shown in Figure 2.

\section{Religious Neurosociology}

In this paper, religion is defined in terms of neurosociology [2] as the combination of neuroscience to study religious brain and sociology to study religious social behaviors. Religious neurosociology consists of religion type, religion formation, and religion learning.

\subsection{Religion Type}

Religion types include social religion to maintain attachment to imaginary ingroup and immune religion to maintain the imaginary mental immune system against adversities. Social religion is defined as the religion based on ingroup-outgroup [15] [18]. Social religion is derived from the natural instinctive attachment to ingroup. For social animals, a clear territorial boundary exists between ingroup and outgroup. In ingroup, individuals share similar interests and attitudes, and produce instinctive feeling of ingroup favoritism as solidarity, community, and exclusivity [28]. Individuals in outgroup outside one's own group are different in interests and attitudes, and produce instinctive feeling of outgroup derogation as inferiority and alienation. According to evolutionary psychologists, this discrimination between ingroup and outgroup has evolved because it enhances group survival in terms of instinctive cooperative connection toward ingroup and instinctive aggressive competition towards outgroup 


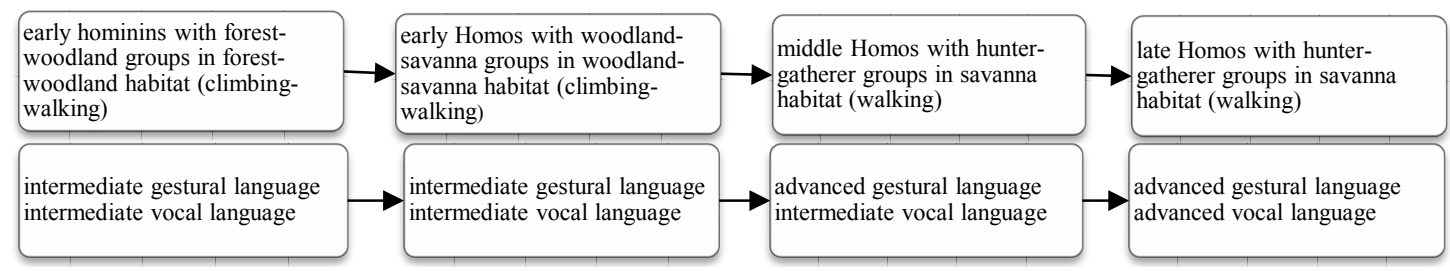

Figure 2. The Human Biological Evolution: The four-step human evolution consists of the early hominins, the early Homos, the middle Homos, and the late Homos. Different steps have different capacities of the feet (climbing tree and walking), different habitats, different divisions of labor in terms of specialist groups, and different language capabilities.

[29]. Such attitudes toward ingroup and outgroup are instinctive, appearing even in babies at few months old as shown in the Infant Cognition Center at Yale University [30]. Ingroup includes kin, home territory, and home culture. Under existential pressure, the natural instinctive attachment to ingroup turns into social religion to maintain attachment to imaginary ingroup.

Immune religion is defined as the religion based on the mental immune system. Immune religion is derived from the natural instinctive mental immune system which is analogous to the immune system [14]. The immune system is a network of cells, tissues, and organs that work together to provide countermeasures against harmful invaders (pathogens). Different immune subsystems provide different countermeasures against different harmful invaders. The balanced immune system has the immune system regulators to balance the activities of the immune system. As the highly imbalanced immune system without the proper immune system regulators, the overactive immune system causes allergies and auto immune diseases as physical disorders against ubiquitous harmful and harmless detected invaders. In the same way, in the mental immune system [14], the different mental immune subsystems provide the different countermeasures against different adversities. The balanced mental immune system has the mental immune system regulators to balance the activities of the mental immune system. As the highly imbalanced mental immune system without the proper mental immune system regulators, the overactive mental immune system causes mental allergies and auto immune diseases as personality-mental disorders against ubiquitous harmful and harmless perceived adversities. The instinctive mental countermeasures in the mental immune system include comforter against hardship, hyperactivity against danger, and phobia against unfamiliarity-uncertainty. Each countermeasure has its regulator to avoid excess countermeasure. The mental immune system is instinctive, because it is mediated by neurotransmitters as in Table 1. Under existential pressure, the natural instinctive natural mental immune system turns into the imaginary mental immune system [14].

\subsection{Religion Formation}

Religion is defined as a set of beliefs and behaviors based on theory of mind that 
Table 1. The mental immune system.

\begin{tabular}{ccccc}
\hline countermeasure & adversity & purpose & $\begin{array}{c}\text { countermeasure } \\
\text { neurotransmitter }\end{array}$ & regulator \\
\hline $\begin{array}{c}\text { comforter } \\
\text { hyperactivity }\end{array}$ & hardship & maintain durability & endorphins & dopamine antagonist \\
phobia & danger & maintain existence & adrenaline & serotonin agonist \\
\hline
\end{tabular}

produces a shared imagination to enhance survival chance under existential pressure. As a result, religion formation requires imagination and existential pressure. The additional requirement is ontogenetic ritualization [19] [20] which involves religious participants mutually shaping each other's behavior during the course of repeated interactions to achieve ritualization. Religion formation is shown in Figure 3.

The transformation from the natural instinctive behaviors to the imaginary behaviors requires imagination, existential pressure, and ontogenetic ritualization. For the attachment to ingroup, the existential pressure is vanished ingroup, including vanished kin, vanished home territory, and vanished home culture. It required imagination to have the attachment to imaginary vanished ingroup. The religious imagination is expressed by symbols, rituals, and imaginary (alternate) mental states [31]. The shared symbols, rituals, and imaginary mental states require ontogenetic ritualization. For imaginary vanished kin, the symbols, rituals, and imaginary mental state involve cemetery, burial rite, and imaginary communication with imaginary vanished kin. For imaginary vanished home territory and culture, the symbols, rituals, and imaginary mental state involve ritualistic festivals, costumes, monuments, and the imaginary prophecies and prayers. Such attachment to imaginary vanished ingroup actually strengthen the social bonds in the existing ingroup, resulting in the enhancement of the survival chance of the social group.

For the mental immune system against adversities, the existential pressure is severe adversities, including severe hardship, severe danger, and severe unfamiliarity-uncertainty. It required imagination to have the imaginary mental immune system against severe adversities. The shared imaginary mental immune system against severe adversities requires ontogenetic ritualization. The imaginary mental immune system strengthens the mental immune system to enhance the survival chance of individuals. The two different sets of imaginary mental immune system are the imaginary supernatural immune system and the imaginary regulatory mental immune system [32] as in Table 2.

The imaginary supernatural mental immune system is currently practiced by Abrahamic religions (Judaism, Christianity, and Islam), while the imaginary regulatory mental immune system is practiced by the Eastern religions (Hinduism, Buddhism, Daoism, and Confucianism) [32]. For the Abrahamic religions, under severe adversities, natural counter measures and natural regulators are replaced by imaginary supernatural countermeasures and imaginary supernatural 
Table 2. The religious imaginary mental immune system.

\begin{tabular}{|c|c|c|c|c|}
\hline $\begin{array}{c}\text { natural } \\
\text { countermeasure }\end{array}$ & adversity & $\begin{array}{l}\text { imaginary supernatural } \\
\text { countermeasure }\end{array}$ & $\begin{array}{l}\text { imaginary supernatural } \\
\text { regulator }\end{array}$ & imaginary mental regulator \\
\hline comforter & hardship & imaginary supernatural love & $\begin{array}{c}\text { imaginary supernatural } \\
\text { providence }\end{array}$ & $\begin{array}{l}\text { imaginary regulatory } \\
\text { meditation/balance }\end{array}$ \\
\hline hyperactivity & danger & imaginary supernatural savior & $\begin{array}{c}\text { imaginary supernatural } \\
\text { providence }\end{array}$ & $\begin{array}{l}\text { imaginary regulatory } \\
\text { meditation/balance }\end{array}$ \\
\hline
\end{tabular}

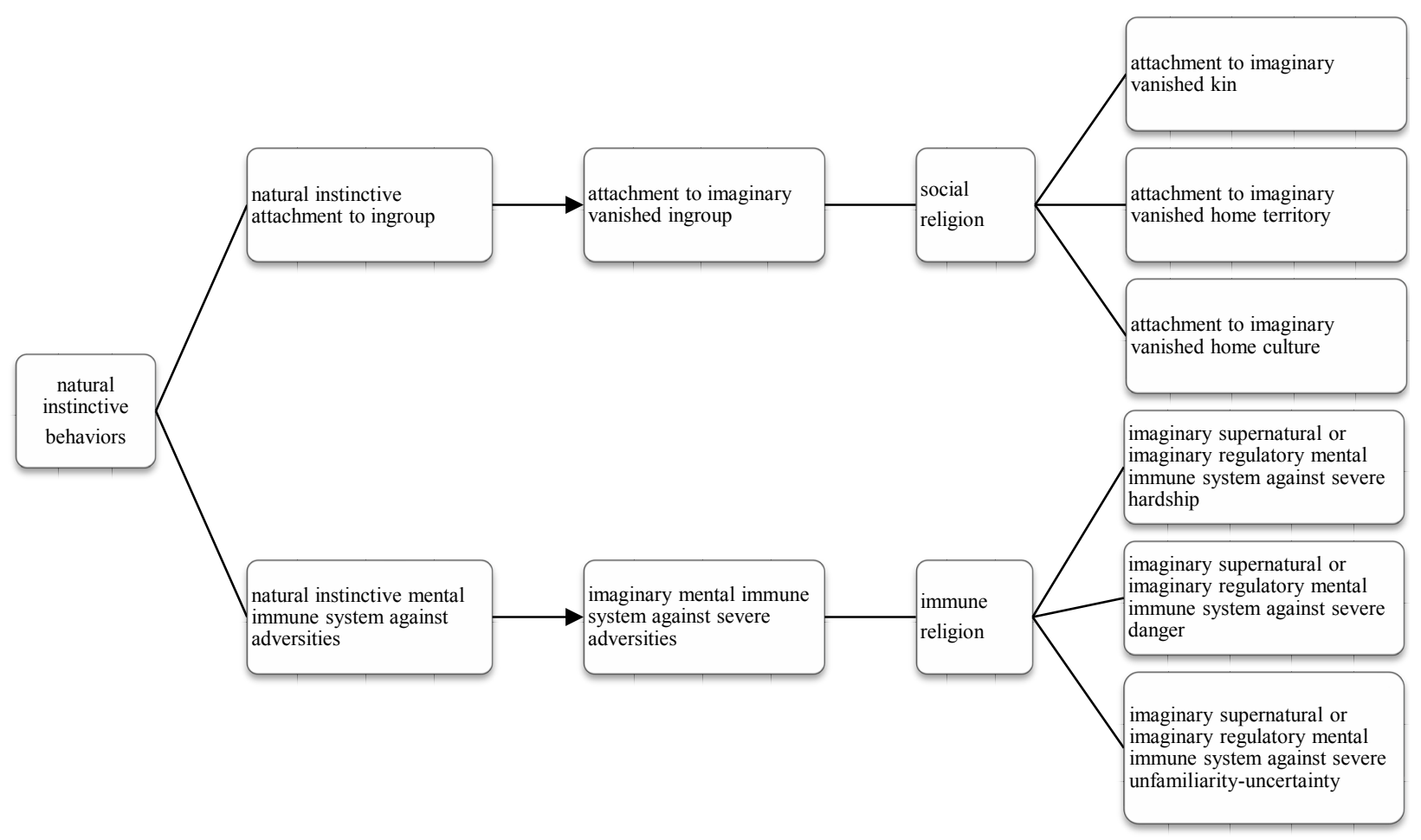

Figure 3. Religion Formation: Under imagination, existential pressure, and ontogenetic ritualization, the instinctive behaviors are transformed into the imaginary behaviors in social religion and immune religion.

regulators. The imaginary supernatural love replaces comforter against severe hardship. The imaginary supernatural love is derived from imaginary companion during pre-juvenile age starting at weaning at the age of about 3 . Without full maternal care, pre-juvenile is forced to initiate. Without sufficient maturity, pre-juvenile inevitably faces stress from hardship. The instinctive countermeasure against hardship is comforter to maintain durability. A common comforter is imaginary companion. Up to two-thirds of children between the ages of 3 and 8 have imaginary companions [33]. Without full maternal care and sufficient maturity, they need imaginary companions to provide comfort in times of stress, boredom, and loneliness, to help them make sense of the adult world, and to overcome traumatic experiences. Taylor feel imaginary companions are common among children and are part of normal social-cognitive development [34]. As juveniles grow older, individualized personal imaginary companions during 
pre-juvenile age are replaced by shared religious supernatural entities to comfort individuals overcoming hardship. For the Abrahamic religions, the shared imaginary supernatural love replaces individualized imaginary companion.

For the Abrahamic religions, the imaginary supernatural savior replaces hyperactivity against severe danger. For Judaism, the confirmation for the miraculous salvation is the miraculous salvation of Israelites from oppression and the deliverance into the Promised Land. For Christianity, the confirmation is the miraculous salvation through Jesus' sacrifice and resurrection. For Islam, the confirmation is the miraculous salvation of Mecca to herald the advent of the Prophet Muhammad. The Abrahamic religions celebrate the miraculous salvations every year. Replacing phobia, the imaginary supernatural authority in power, laws, and traditions provides the phobia (fear) against moving to unfamiliar-uncertain way of life (sins). According to the Bible, the fear of the Lord is the beginning of knowledge (Proverbs 1:7). The imaginary supernatural authority is expressed as righteousness. For the Abrahamic religions, the imaginary supernatural authority (righteousness) is written in the sacred scriptures.

The imaginary supernatural providence (wisdom) as the religious regulator to regulate the religious immune system, and prevents overactive religious countermeasure against ubiquitous perceived adversity as in personality-mental disorders. Believing in the imaginary supernatural providence, a believer in the imaginary supernatural love looks beyond prevailing severe hardship to the coming of the imaginary supernatural love, resulting in the elimination of the overactive imaginary supernatural love against ubiquitous perceived hardship. Believing in the imaginary supernatural providence, a believer in the imaginary supernatural savior looks beyond prevailing severe danger to the coming of the supernatural salvation, resulting in the elimination of the overactive imaginary supernatural salvation against ubiquitous perceived danger. Believing in the imaginary supernatural providence, a believer in the imaginary supernatural authority looks beyond prevailing unfamiliarity-uncertainty (sins) to the coming of the imaginary supernatural authority, resulting in the elimination of the overactive imaginary supernatural authority against ubiquitous perceived unfamiliarity-uncertainty. The imaginary supernatural providence provides a way for delayed gratification.

The imaginary regulatory mental immune system is practiced by the Eastern religions (Hinduism, Buddhism, Daoism, and Confucianism). For the imaginary regulatory mental immune system, the countermeasures are basically the natural countermeasures to allow natural emotion to occur. The countermeasures against severe hardship and danger are natural comforter and natural hyperactivity, respectively. On the other hand, the countermeasure against unfamiliarity-uncertainty is natural rationality based on the rational brain which matures at about 25 years old as young adult. As a result, adults use mostly natural rationality countermeasure against unfamiliarity-uncertainty, while children use mostly natural phobia countermeasure against unfamiliarity-uncertainty. The Eastern 
religions with the adulthood mental immune system use rationality countermeasure against unfamiliarity-uncertainty, while the Abrahamic religions with the childhood mental immune system use phobia countermeasure against unfamiliarity-uncertainty [32]. The Abrahamic religions basically regard gods as heavenly parents who treat the believers as their children.

For the imaginary regulatory mental immune system, the regulators are imaginary mental regulators to prevent overactive mental immune system. The imaginary mental regulators involve meditation and balance based on imaginary (alternate) mental states. For an example, one of the imaginary mental states is the concentration (focus) on a mantra as a form of concentration meditation [35]. Meditations include nonjudgmental mindfulness meditation of the present with open-focus and concentration meditation with focus. These meditations as the imaginary mental regulators minimize overactive comforter against ubiquitous perceived hardship and overactive hyperactivity against ubiquitous perceived danger.

Another imaginary mental regulator is imaginary balance. A good example of imaginary balance is the imaginary balance between yin and yang to keep harmony [36]. A most important imaginary balance is imaginary balanced adversity-fortune to reach harmony. Whenever one thinks too much about adversity, imagine about possible fortune after adversity. Equally, whenever one thinks too much about fortune, imagine about possible adversity after fortune. Imaginary balance encourages the middle (mean), and discourages the extreme. The first chapter of the Book of Mean from Confucianism describes how to deal with emotion, "When joy, anger, sorrow and pleasure have not yet arisen, it is the state of equilibrium. When they arise to their appropriate levels, it is the state of harmony. The state of equilibrium is the great base of all-under heaven. The state of harmony is the universal path to be pursued. When the states of equilibrium and harmony are actualized, Heaven and Earth are in their proper positions, and all things are nourished." The goals of the regulated mental immune systems are to be in the states of equilibrium (idle regulated mental immune system) without arising emotion from countermeasures, and in the state of harmony through imaginary balance regulator with arising emotion from countermeasures.

The imaginary mental regulator to control overactive rationality against ubiquitous perceived unfamiliarity-uncertainty is the acceptance of the unknown. Confucius said: "... Recognizing that you know what you know, and recognizing that you do not know what you do not know-this is knowledge." (Analects 2:17) Buddha refused to speculate about gods and afterlife which were largely unknown.

\subsection{Religious Learning}

This paper proposes that the origin of religion is derived from theory of mind. Theory of mind which is to recognize (imagine) that the others exist to think for 
themselves. According to a PET study, theory of mind activates the medial prefrontal node to handle the mental state of the self, the superior temporal sulcus to detect the behavior of other animals and analyzes the goals and outcomes of this behavior, and the inferior frontal region to maintain representations of actions and goals [37]. Theory of mind supplies the cognitive basis for the belief in imaginary (supernatural) agents that think for themselves. According to Kapogiannis and Deshpande in the functional MRI study of the brains of both self-declared religious and non-religious individuals, individuals with stronger theory of mind activity were found to be more religious [5]. Thinking about God activates brain regions associated with theory of mind [6]. Autism with the deficits in theory of mind is linked to lower belief in God [7].

Theory of mind is to recognize (imagine) that the others exist to think for themselves, so it is closely related to imagination. Imagination is the mental ability to produce images, thoughts, and feelings independent of immediate input perceptions such as vision and hearing. Autistic individuals with problems in imaginative capacities and pretend plays are incapable of theory of mind [8] [9] [10]. Robust religion is unique to humans, because robust theory of mind is unique to humans [11]. According to Maurice Bloch [12], the first widespread human religion was derived from the imagination to produce imaginary female figurines and imaginary cave paintings to helps them to survive under existential pressure at the time of the Upper Paleolithic Revolution [13].

According to the functional MRI study of cognitive and neural foundations of religious belief by Kapogiannis et al., the three psychological dimensions of religious belief are God's perceived level of involvement, God's perceived emotion, and doctrinal/experiential religious knowledge which functional MRI localizes within networks processing theory of mind regarding intent and emotion, abstract semantics, and imagery [6]. Therefore, for religious learning, the imagination in religious imaginary behaviors is produced by the mental synthesis of imaginary agents (symbols, rituals, or alternate mental states) from theory of mind with the memories of natural instinctive behaviors. According to Vyshedskiy [21], mental synthesis for imagination is the conscious purposeful prefrontal cortex-driven process of synthesizing a novel mental image from parts stored in memory. Semantic memory is the root of imagination [38]. Mental synthesis is neurologically different from the other key components of imagination: simple memory recall and dreaming. Different from dreaming, which is spontaneous and not controlled by the prefrontal cortex, mental synthesis is controlled by and completely dependent on the intact lateral prefrontal cortex. Different from simple memory recall that involves activation of a single neuronal ensemble, mental synthesis is a motor act that involves active combination of two or more neuronal ensembles.

For social religion, the imagination in the religious imaginary emotional attachment to vanished ingroup is produced by the mental synthesis of the symbols, rituals, and imaginary mental states for vanished ingroup with the memo- 
ries and historical records of vanished kin, vanished home territory, and vanished home culture. The end result of the religious imaginary emotional attachment to vanished ingroup is to strengthen the natural instinctive emotional attachment to existing ingroup that has shared vanished ingroup.

The intensive devotion to ingroup can reach mental peak. For an example, the devotion of sport fans to home sport team is the devotion to ingroup in terms of home territory. During sport events, sport fans can reach the frenzy state at the moment of winning. In the same way, the intensive devotion to imaginary ingroup can also reach mental peak. For an example, a study using functional magnetic resonance imaging scans in 19 devout Mormons demonstrated that nucleus accumbens activation preceded peak spiritual feelings by $1-3$ second [39]. (The shell of the nucleus accumbens is involved in the cognitive processing of reward.) According to the study, the association of abstract ideas and brain reward circuitry may interact with frontal attentional and emotive salience processing, suggesting a mechanism whereby doctrinal concepts may come to be intrinsically rewarding and motivate behavior in religious individuals.

For immune religion, the imagination in the religious imaginary supernatural mental immune system is produced by the mental synthesis of the symbols and rituals for supernatural with the memories of the instinctive countermeasures and regulators in the instinctive mental immune system. The natural instinctive mental immune system consists of the natural instinctive countermeasures and natural instinctive regulators without supernatural. The end results of the religious imaginary supernatural instinctive mental immune system and the natural instinctive mental immune system are similar. The natural instinctive comforter against hardship such as in the case of the comforter manifested as the runner's high after running (stress) for a long time [40] is similar to the comfortable supernatural love against hardship. The natural instinctive hyperactivity against danger is similar to the miraculous supernatural salvation against danger. The natural instinctive phobia against unfamiliarity-uncertainty is similar to the righteous supernatural authority that provides phobia against unfamiliarity-uncertainty (sins). The natural regulator against ubiquitous perceived adversities is similar to the supernatural providence (wisdom) against ubiquitous perceived adversities. The religious imaginary supernatural mental immune system is useful under existential pressure.

For immune religion, the imagination in the religious imaginary regulatory mental immune system is produced by the mental synthesis of the imaginary (alternate) mental states with the memories of the instinctive regulators in the instinctive mental immune system. The natural instinctive mental immune system consists of natural instinctive countermeasures and natural instinctive regulators without alternate mental state, while the religious imaginary regulatory mental immune system consists of natural instinctive countermeasures and religious imaginary regulators. The end results of the religious imaginary mental regulators and the natural instinctive regulators are similar. The natural regula- 
tors against ubiquitous perceived adversities are similar to the imaginary mental regulators (imaginary regulatory meditation and balance) against ubiquitous perceived adversities. Meditation has been investigated to show the decreases in emotional interference by unpleasant stimuli and in the time to return to emotional baseline after stress [16]. The religious imaginary regulatory mental immune system is useful under existential pressure.

\section{The Premodern Religious Evolution}

In biological evolution, a most important factor in evolution is habitat. Different species were evolved in different habitats. In the same way, different religions have been evolved in different religious habitats. A most important factor in religious habitat is the size of religious involvement. Different religious habitats with different sizes of religious involvement require different religions. As human civilization advances, the size of religious involvement inevitably increases in the order of premodern local society habitat, modern regional society habitat, and postmodern global society habitat. As the religious habitat changes, an old religion may not change with new habitat, but the actual religious practice of believers in their daily life changes with new habitat willingly or reluctantly. This paper proposes that the religions consist of the premodern imaginative religion for local society habitat starting from bipedalism, the modern rational imaginative religion for regional society habitat starting from the Axial Age, and the postmodern diverse rational imaginative religion for global society habitat starting from the Information Revolution. The religious evolution is shown in Figure 4.

The premodern religion evolution started from the original of religions as described in the previous section. In the study using a suite of phylogenetic comparative methods to investigate the early evolution of religion of hunter-gatherer, Peoples, Duda, and Marlowe found the oldest trait of religion, present in the most recent common ancestor of present-day hunter-gatherers, was animism. Belief in an afterlife emerged, followed by shamanism. Ancestor worship and high gods who are active in human affairs were absent in early hunter-gatherer, suggesting a deep history for the egalitarian nature of hunter-gatherer societies [41]. The premodern religious evolution is shown in Figure 5.

\subsection{Animism}

With imagination through theory of mind, a hominin could construct an entire

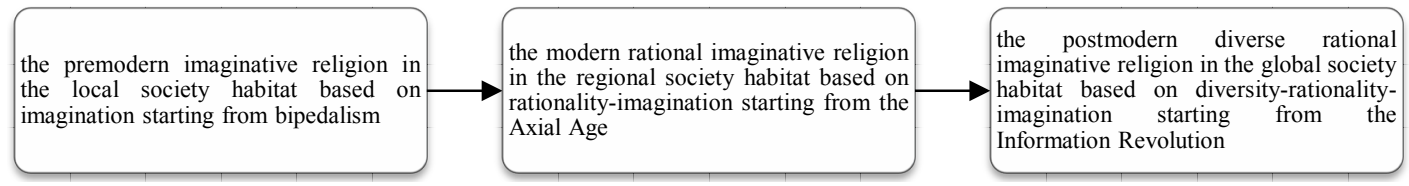

Figure 4. The Religious Evolution: The religious evolution consists of the premodern religion, the modern religion, and the postmodern religion based on habitats (society sizes) and the principles of religions. 


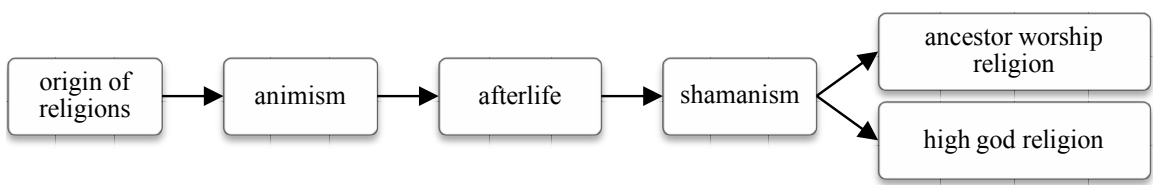

Figure 5. The Premodern Religious Evolution: The premodern religion starting from bipedalism occurred before the Axial Age.

imaginary world where all things had imaginary agents that were animated and alive, and could think for themselves. This imaginary world was the base of animism that believed that all things were animated and alive [42] [43]. Under intense existential environmental pressure, symbols, rituals, and alternate mental states were created as the imaginary embodied agents to provide particular powers to enhance the mental immune system. One example is the imaginary female figurines and the imaginary cave painting during the Upper Paleolithic Period [13]. The Upper Paleolithic Period was a very difficult period that produced intense existential pressure to generate imaginary symbols, rituals, and alternate mental states. During the harsh Upper Paleolithic Period, women (gatherers) were under intense existential pressure to have successful fertility, while men (hunters) were under intense existential to have strong vitality. The imaginary female figurines and cave paintings appeared during the period. The imaginary exaggerated and distorted female figurines were miniature sculptures of well-rounded female nudes with an overemphasis of the fleshy parts of the body (buttocks, stomach and chest). The sexual accent on the female breasts and the posterior are assumed by many to connote signs of fertility. According to Alan F. Dixson and Barnaby J. Dixson, these female figurines symbolized and brought the hope for a well-nourished and fertile community to change the fate of facing grim winters and a scarce food supply [44]. The imaginary female figurines provided the power of have successful fertility by enhancing the comforter countermeasure in the mental immune system against hardship. In the imaginary cave paints, the animals were mystic large strong animals or mystic animals with horns that symbolized maturation and strength. According to David Lewis-Williams [45], the imaginary cave paintings involved hallucinatory or trance states by drugs or repetitive rhyme. The mystic animal pictures were conceived during the trance states. These cave paintings symbolized and brought the hope for a vital and powerful community to change the fate of facing grim winters and a scarce food supply. The imaginary cave paintings provided the power to have strong vitality by enhancing the comforter countermeasure in the mental immune system against hardship.

\subsection{Afterlife}

In the study by Peoples, Duda, and Marlowe, the belief in afterlife came after animism. While animism mostly and directly enhanced the mental immune system under existential environmental pressure, afterlife was mostly and directly enhanced ingroup under existential social pressure. The inclusion of imaginary 
vanished ingroup members in their afterlife increased the ingroup size, territory, and cohesion. Under intense existential social pressure, symbols, rituals, and alternate mental states were created as the imaginary embodied agents to provide particular powers by enhancing ingroup. Intense existential social pressure came from entirely different and intensely hostile outgroup. Intense existential environmental pressure was more prevalent than intense existential social pressure, so the religion of animism came before the religion of afterlife.

One possible example of afterlife is the burial site of Homo naledi. Home naledi's fossils of at least fifteen individuals, amounting to 1550 specimens, have been excavated from in the Rising Star cave system [46]. There is no evidence that the cave was a living space, there are no carnivore and other animals' remains to suggest they were dragged there by carnivores, and the bones do not indicate traumatic injuries from precipitous drop. In fact, the way that the bones were scattered at different depths in the cave soil suggests that they arrived there at different periods of time, so one possible conclusion is the bodies were placed there by some kind of ritual burial practice which raises the possibility that Homo naledi had a sense of the afterlife [4]. The age of Homo naledi and associated sediments in the Rising Star Cave were determined to be between 236,000 and 335,000 years ago [47]. The brain size was small about half of the size of the human brain, like Homo habilis which lived in about 2 million years ago, Homo naledi still retained some body features for climbing trees. It was very odd. Homo naledi lived at a time when Homo heidelbergensis with much large brain and without body features for climbing trees was fully established. At this time, Homo heidelbergensis was making advanced stone tools. Homo naledi appeared to be a backward minor homo species among mostly much advanced homo species. As a result, Homo naledi was under the intense social pressure from the surrounding advanced homo species. Under this intense social pressure, Homo naledi created a ritual burial practice as shown in the burial site in the Rising Star cave system. The result was the enhancement of the survival chance for Homo naledi as social group.

\subsection{Shamanism}

In the study by Peoples, Duda, and Marlowe, the belief in shamanism came after animism and afterlife. Shamanism was essentially practiced by religious specialists (shamans) who specialized in using symbols, rituals, and alternate mental states to interact with the imaginary world (spirit world) to channel powers into this world [48] [49]. Shamans were particularly imaginative people who could convincingly use imagination to provide the power for the enhancement of survival chance under existential pressure. The followers of shaman believed in the imagination of shaman who provided the power to enhance survival chance under existential pressure. Existential pressure could be environmental pressure or social pressure. As a result, shamans could enhance ingroup under existential social pressure and the mental immune system under existential environmental 
pressure.

One example of shamanism is Hmong Shamanism [50]. The Hmong people with a 5000-year history starting from China continue to maintain and practice shamanism. A Hmong shaman chosen by the shaman God is responsible to bring harmony to the individual, their family, and their environment by various symbols, rituals, and alternate state (trance). In one ceremony, the shaman dances with a black cloth over the face and with the sound of drum in the background. The shaman is then in a trance, chanting, and talking to someone who isn't really there. The shaman is in the journey to the spirit world. The shaman greets the spirits at the beginning of a journey, and tells them what answers the shaman seeks. The answers eventually come. In the end the shaman thanks the spirits.

\subsection{Ancestor Worship Religion and High God Religion}

In the study by Peoples, Duda, and Marlowe, ancestor worship and high gods who are active in human affairs were absent in early humans, suggesting a deep history for the egalitarian nature of early human societies. Ancestor worship religion and high god religion emerged with the advent of the Agricultural Revolution. During the Agricultural Revolution, the advanced agricultural method allowed drastically improved the productivity to support population increases by more intensive use of the same piece of land. Consequently, the Agricultural Revolution led to large social group that became hierarchical with high rulers on the top. Large hierarchic societies required the high supernatural that demanded respect and obedient in the same way as the human high rulers [51], resulting in ancestor worship religion and high god religion.

The agricultural society faced intense existential social pressure and existential environmental pressure. The territorial expansions from large social groups destroyed the clear and stable boundaries among large social groups. It became difficult to maintain ingroup against outgroup, resulting in intense existential social pressure. Agricultural society required to stay in the same place, so it was more prone to the periodic local natural disaster, unlike the hunter-gatherer society that was free to move away from local natural disaster. The constant population pressure and the periodic natural disasters caused the deficient resource and security, so famine only became a common problem for agriculturalists [52]. The hunter-gatherers were averaged 6 inches taller than agricultural peoples up to 100 years ago. The life expectancy in the agricultural society was actually shorter than in the early hunter-gatherer society [53]. According to Goodman and Armelagos in the study to compare the remains of Native American hunter-gatherers with their agricultural grandchildren in Dickson's Mounds in Illinois, the agricultural population showed significant increases in enamel defects, iron-deficiency anemia, bone lesions, and degenerative spinal conditions. Life expectancy at birth dropped from 26 to 19 [54]. War was less common in the early hunter-gatherer society than in the agricultural society [55]. Therefore, ex- 
istential environmental pressure was greater in the agricultural society than in the early hunter-gatherer society. Consequently, the agricultural society under intense existential social and environmental pressure was more religious than the early hunter-gatherer society. In fact, simple egalitarian hunter-gatherer groups generally hold fewer religious beliefs and participate in less ritual than more complex groups [56]. Hunter-gatherer religions are seldom religions of protest or evangelism [57]. Under such large social group and intense existential pressure, all major religions, including ancestor worship religion and high god religion started to form.

Ancestor worship is defined as belief that the spirits of ancestors remain active in another realm where they may influence the living, and can be influenced by the living [58]. One example of ancestor worship is the ancestor worship in China. The intense existential social and environmental pressure to face unexpected fatality for ingroup and individuals produced a special way to achieve imaginary immortality for survival. Each individual in the ingroup is responsible for the immortality of ingroup and for the individual's immortality by having children and the veneration of ancestors. Children are important because they can provide for the spirits of their parents after death. Family members who venerate their ancestors with strict ritual find comfort that they provide the spirits of their ancestors, and their spirits are provided by their children after death. Ancestor worship is important in Confucianism. In the Hofstede's five dimensions (power distance, uncertainty avoidance, individualism/collectivism, masculinity/femininity and long-term orientation) to represent differences among national cultures [59], the culture under Confucianism has extremely and uniquely strong long-term orientation based on the immortality in ancestor worship.

"High gods" is defined as single, all-powerful creator deities who may be active in human affairs and supportive of human morality [60]. The intense existential social and environmental pressure to face unexpected fatality for ingroup and individuals produced imaginary high gods who are active in human affairs and supportive of human morality to keep the integrity of ingroup against outgroup, and supportive of individuals' wellbeing. High god religion includes the Abrahamic religions whose gods are basically heavenly parents [32].

\section{The Modern Religious Evolution}

The modern religion is the modern rational imaginative religion based on imagination-rationality. According to Max Weber, modernity is directly related to rationality [61]. Human capacity of reasoning in the frontal lobe of the neocortex for the rational brain allows human society to develop rational system. The modern rational imaginative religion is derived from the combination of the premodern imaginative religion and the rational system as shown in Figure 6.

\subsection{The Rational Brain and Rationality}

Human capacity of reasoning in the frontal lobe of the neocortex for the rational 


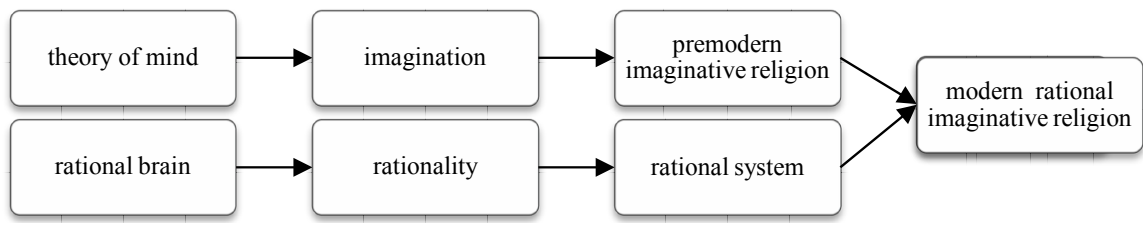

Figure 6. The Formation of the Modern Religion: The formation of the modern rational imaginative religion is derived from the combination of the premodern imaginative religion and rationality from the rational brain.

brain allows human society to develop rational system. The expansion of the rational brain in the neocortex accelerated in Homo erectus. Homo erectus emerged when the arid climate that intensified about 2 million years ago transformed a part of African into the savanna habitat. Due to the loss of tress to climb, the feet were evolved to the feet for walking and running only, and were not good in climbing trees. The previous Homo species, such as Homo habilis, still retained some body features for climbing trees. Due to the loss of the foods obtained from trees, Homo erectus were forced to hunt animals in savanna, resulting in the formation of the gatherer group to gather plant foods in savanna and the hunter group to hunt animals in savanna. The intake of highly nutritious meat allowed the energy-fat hungry brain to expand [62]. The calorie content of meat is high. The brain is a very fatty organ, and meat is a much better source of the necessary fats than plant foods. The stones tools were able to cut and grind the foods into digestible forms [63]. For Homos erectus, savanna with many predators was a difficult place to survive. As a result, under the evolutionary pressure of difficult savanna and the nourishment of meat, the brain expanded to increase intelligence for advanced stone tools and advanced language to survive in savanna [64] [65]. The brain size increased rapidly with the sizes between 750 and $1225 \mathrm{cc}$. The body size also increased. Homo erectus at least in the larger specimens had double the brain size of Homo habilis, and the body size was much closer to modern human body size than Home habilis.

As a result, the rational brain in the neocortex expanded quickly. The rational brain produces rationality. Homo erectus used rationality to enhance their survival chance under existential pressure. With the expanded rational brain, Homo erectus was adaptable enough to migrate out of Africa and adapt to the various environments outside of Africa, and survived in many locations for a very long time between about 1.89 million and 143,000 years ago [66].

\subsection{The Axial Age and the Modern Religion}

In the agricultural society, different local social group with different religious imaginations had different imaginary premodern religions. To enforce imaginary premodern religions in the agricultural society without clear boundary, the premodern religions became authoritative religions enforced by religious authorities against the religious contamination from other religions. Initially, each religion involved a local society [22]. The superiority of an authoritative religion 
was determined by military conquest. Eventually, in each region, a dominant power dominated each region. During the Axial Age [67] from about the eighth to the third century BCE, the dominant regional powers had lost their powers, and new ones were still not ready [68], for an example, during the Axial Age, the dominant regional power Zhou in the China region was disintegrated, and the established religion lost its power. Without established religion, some thinkers doubted about religious imaginations in terms of religious symbols, rituals, and alternate mental states. Confucius who was a thinker during the Axial Age said, "Working to give the people justice and paying respect to the spirits, but keeping away from them, you can call wisdom." (Analects 6:22) The thinkers such as Buddha, Confucius, Laozi, Socrates, Plato, and Aristotle refused to use religious imagination to claim themselves as the authoritative representatives of imaginary gods. They used reasons in terms of rational systems to enhance human survival chance under existential pressure. At the same time, they did not abandon religious imagination. They continued to use symbols, rituals, and alternate mental states through the combination of imagination and rationality. For examples, in Platonism as the philosophy of Plato, the existence of rational abstract objects, such as numbers, exist in an imaginary world independent of both the perceived external world and the internal world of consciousness. Buddha did not think religious symbols and rituals were helpful to reduce suffering, but he still used the alternate mental states in meditation to reduce suffering. Confucius built a social system based on rational reciprocal relationships among family members and citizens, but he still respected the Heaven (god). Confucius said, "There are three things of which the superior man stands in awe. He stands in awe of the ordinances of Heaven. He stands in awe of great men. He stands in awe of the words of sages." (Analects 16:8) The Axial Age started modernity and the modern rational imaginative religion based on rationality and imagination. In the West, modernity reappeared during the Renaissance (about 1420-1630). The Renaissance was influenced by classical Greek philosophy. A founder of modernity is Rene Descartes (1596-1650) who promoted independent reason (I think, therefore I am).

\subsection{The Industrial Revolution}

The Industrial Revolution started in about 250 years ago. The Industrial Revolution replaced an economy based on manual labor by one dominated by machinery. The dramatic increase in productivity lifted most people from the poverty. The Industrial Revolution started in the mid-18th century and early 19th century in Britain and spread throughout the world. The Industrial Revolution has improved human living condition tremendously. Intense existential environmental pressure in the agricultural society has been greatly reduced in the industrial society. Without intense existential environment pressure, people get less religious, and irreligion has become more common in the industrious countries such as in the industrious and relatively homogenous European countries 
without high existential social pressure [69].

\section{The Postmodern Religious Evolution}

Postmodernity started from the late 20th century [70] about the time of Information Revolution involving extensively computers and wired and wireless networks to store, manipulate, and transmit information. The postmodern religion as the postmodern diverse rational imaginative religion is derived from global cultural diversity and modern rational imaginative religion as shown in Figure 7.

\subsection{Globalization from Global Interdependence and Global Information Network}

Globalization is derived from global interdependence and global information network. Global communication through information technology allows global interdependence in terms of global division of labor. Different countries specialize in producing different goods, services, and raw materials. Free competitive international trade benefits trading countries where each country develops its own "trade specialty" with comparative advantage in international trade. Free competitive international trade provides economic growth as shown in higher economic growth for the countries with free trade than the countries with protectionism. Today, very few products are manufactured entirely in a single country, and people consume products daily from all over the world.

The rise of digital media, especially the internet, has led to the global information network that allows people to spread news, art, music, fashion, and political movement globally, and communicate with people globally. Distance is no longer a big barrier in the spread of information. Globalization is derived from global interdependence and global information network.

\subsection{Global Cultural Diversity from Globalization and Multiple Cultures}

In postmodern time, globalization is a norm, not a choice. In the world, there

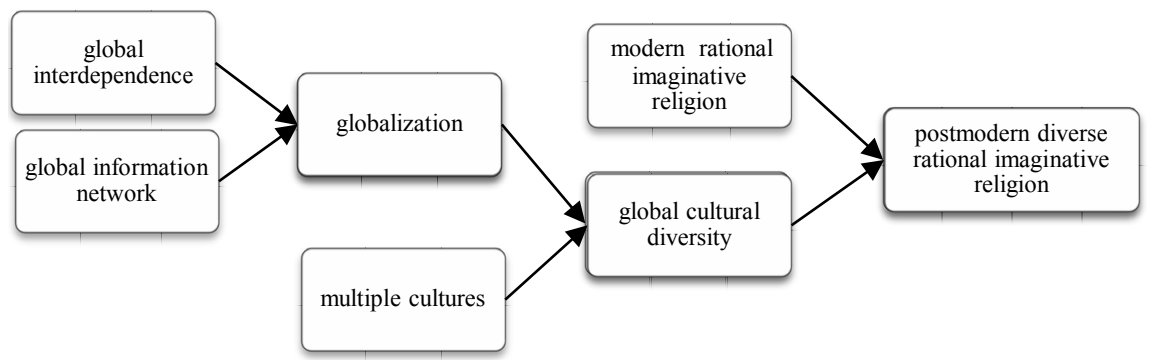

Figure 7. The Formation of the Postmodern Religion: The formation of the postmodern diverse rational imaginative religion is through the combination of the modern rational imaginative religion and global cultural diversity which is derived from multiple cultures and globalization from the combination of global interdependence and global information network through the Information Revolution. 
are multiple different cultures, so globalization must involve global cultural diversity. Global cultural diversity with multiple different cultures does not appear to have the universal standards for objective reality, morality, truth, human nature, reason, language, and social progress. Such absence of the universal standards in global cultural diversity produces postmodernism [71]. Postmodernism is a broad movement that developed in the mid to late 20th century. Postmodernism is characterized by skepticism, subjectivism, relativism, pluralism, irreverence, and self-referentiality. It distrusts grand narratives, ideologies, and various universal tenets. Postmodernism proclaims that claims to knowledge and truth are products of social, historical or political discourses or interpretations, and are therefore contextual. Basically, postmodernism reflects global cultural diversity with multiple cultures. Postmodernism is also a reflection of low or no existential pressure in postmodern consumerism which allows consumers to comfortably and leisurely pick and mix various products [72].

\subsection{The Postmodern Religion from Global Cultural Diversity and the Modern Religion}

When the religious involvement expanded from premodern local society habitat to modern regional society habitat, rationality was added to imagination to form the modern rational imaginative religion. In the modern rational imaginative religion, the rational thinkers did not abandon imagination. In the same way, when the religious involvement expands from modern regional society habitat to postmodern global society habitat, diversity is added to rationality and imagination to form the postmodern diverse rational imaginative religion. When people face existential pressure in various occasions in their lives, they need urgently rationality and religious imagination to enhance survival chance under existential pressure, and they do not have time and energy to pick and mix various options comfortably and leisurely as in postmodernism. As a result, the postmodern religion that helps people under existential pressure [73] cannot abandon rationality and imagination, and cannot follow completely postmodernism which is under low or no existential pressure. The postmodern diverse rational imaginative religion recognizes the need of global cultural diversity to tolerate and understand diversity, but under existential pressure, the existential concern is immediate and close to home, and only rationality and imagination instead of diversity can enhance survival chance under existential pressure.

One example of the postmodern diverse rational imaginative religion is radical orthodoxy which is a branch of postmodern theology [74]. In radical orthodoxy, there is no sharp distinction between rationality and imaginative revelation. The world is best understood through interactions with God, culture, language, history, technology, and theology, even though a full understanding of God is never possible. A full appreciation of the physical world is only possible through a belief in transcendence. Finally, salvation is found through interactions with God and others. 


\section{Summary and Conclusions}

In summary, the paper proposes the evolutionary origin of religions, religious neurosociology, and the religious evolution. The evolutionary origin of religions is based on theory of mind as the product of interdependent division of labor between the forest specialist group (women and small children) and the woodland specialist group (men) in early hominins who lived in the mixed forest-woodland habitat. To complement each other's work without interfering each other's work, one specialist group had to recognize (imagine) that the other specialist group existed to think for themselves and to do different works. The result was theory of mind which is to recognize (imagine) that the others exist to think for themselves. (The forest-woodland groups became the hunter-gatherer groups for the Homo species in the savanna habitat.) Under existential pressure, hominins invented imaginary specialists as imaginary agents who existed to think for themselves and to do different works in imaginary division of labor to enhance survival chance. The result was religion with imaginary behaviors. Therefore, religion is defined as a set of beliefs and behaviors based on theory of mind that produces a shared imagination to enhance survival chance under existential pressure, such as the religious reinforcement of social bonds to enhance the survival chance of social group and the religious relief of stress and anxiety to enhance the survival chance of individuals.

Religious neurosociology combines neuroscience to study religious brain and sociology to study religious social behaviors. Religious neurosociology consists of religion type, religion formation, and religion learning. Religion types include social religion to maintain attachment to imaginary ingroup and immune religion to maintain the imaginary mental immune system against adversities. In religion formation, under imagination, existential pressure, and ontogenetic ritualization, the natural (un-imaginary) instinctive attachment to ingroup turns into the attachment to imaginary ingroup for social religion, and the natural instinctive mental immune system against adversities turns into the imaginary mental immune system for immune religion. Religion learning is through the imagination derived from mental synthesis. The religious evolution consists of the premodern imaginative religion for local society habitat starting from bipedalism, the modern rational imaginative religion for regional society habitat starting from the Axial Age, and the postmodern diverse rational imaginative religion for global society habitat starting from the Information Revolution.

In conclusion, instead of explaining religion by religion, religious neurosociology explains religion by neurosociology. Religious neurosociology and the religious evolution provide a comprehensive understanding of religion. In religious neurosociology, the religious brain is the imaginative brain modified in some cases by rationality and diversity, and the religious social behaviors are imaginary social behaviors modified in some cases by rationality and diversity. The religious evolution is the evolution of human imagination to enhance survival chance under existential pressure, analogous to biological evolution as the 
evolution of new biological trait to enhance reproductive success under evolutionary pressure.

\section{Conflicts of Interest}

The authors declare no conflicts of interest regarding the publication of this paper.

\section{References}

[1] Durkheim, E. (1965) The Elementary Forms of the Religious Life. Free Press, New York.

[2] Kalkhoff, W. (2016) Developments in Neurosociology. Sociology Compass, 10, 242-258. https://doi.org/10.1111/soc4.12355

[3] Dunbar, R. and Shultz, S. (2010) Bondedness and Sociality. Behaviour, 147, 775-803. https://doi.org/10.1163/000579510X501151

[4] Janssen, L. (2016) Standing on the Shoulders of Giants: Genesis and Human Origins. Wipf and Stock Publishers, Eugene, 118.

[5] Kapogiannis, D., et al. (2014) Brain Networks Shaping Religious Belief. Brain Connectivity, 4, 70-79. https://doi.org/10.1089/brain.2013.0172

[6] Kapogiannis, D., et al. (2009) Cognitive and Neural Foundations of Religious Belief. Proceedings of the National Academy of Sciences, 106, 4876-4881. https://doi.org/10.1073/pnas.0811717106

[7] Norenzayan, A., Gervais, W. and Trzesniewski, K. (2012) Mentalizing Deficits Constrain Belief in a Personal God. PLoS ONE, 7, e36880.

https://doi.org/10.1371/journal.pone.0036880

[8] Scott, F. and Baron-Cohen, S. (1996) Imagining Real and Unreal Objects: An Investigation of Imagination in Autism. Journal of Cognitive Neuroscience, 8, 400-411.

[9] Angus, D., et al. (2015) Limitations in Social Anticipation Are Independent of Imaginative and Theory of Mind Abilities in Children with Autism but Not in Typically Developing Children. Autism, 19, 604-612.

https://doi.org/10.1177/1362361314537911

[10] Chan, P., et al. (2016) Theory of Mind Deficit Is Associated with Pretend Play Performance, but Not Playfulness, in Children with Autism Spectrum Disorder. Hong Kong Journal of Occupational Therapy, 28, 43-52. https://doi.org/10.1016/j.hkjot.2016.09.002

[11] Heyes, C. (2015) Animal Mindreading: What's the Problem? Psychonomic Bulletin \& Review, 22, 313-327. https://doi.org/10.3758/s13423-014-0704-4

[12] Bloch, M. (2006) Why Religion Is Nothing Special but Is Central. Philosophical Transactions of the Royal Society B, 363, 1499.

[13] Chung, D. (2016) The Human Religious Evolution. Open Journal of Social Sciences, 4, 75-90. https://doi.org/10.4236/jss.2016.43013

[14] Chung, D. (2018) The Mental Protection System for Protective Behaviors: The Social Brain and the Mental Immune System. Journal of Behavioral and Brain Science, 8, 31-55. https://doi.org/10.4236/jbbs.2018.81003

[15] Norenzayan, A., et al. (2016) The Cultural Evolution of Prosocial Religions. Behavioral and Brain Sciences, 39, e1. https://doi.org/10.1017/S0140525X14001356

[16] Tang, Y., Hölzel, B. and Posner, M. (2015) The Neuroscience of Mindfulness Medi- 
tation. Nature Reviews Neuroscience, 16, 213-225. https://doi.org/10.1038/nrn3916

[17] Krupenye, C., et al. (2016) Great Apes Anticipate That Other Individuals Will Act According to False Beliefs. Science, 354, 110-114.

https://doi.org/10.1126/science.aaf8110

[18] Norenzayan, A. and Gervais, W. (2012) The Cultural Evolution of Religion. In: Slingerland, E. and Collard, M., Eds., Creating Consilience: Integrating the Sciences and the Humanities, Oxford University Press, Oxford, 243-265.

[19] Tomasello, M., George, B., Kruger, A., Farrar, J. and Evans, E. (1985) The Development of Gestural Communication in Young Chimpanzees. Journal of Human Evolution, 14, 175-186. https://doi.org/10.1016/S0047-2484(85)80005-1

[20] Plooij, F. (1978) Some Basic Traits of Language in Wild Chimpanzees? In: Lock, A., Ed., Action, Gesture and Symbol: The Emergence of Language, Academic Press, London, 111-131.

[21] Vyshedskiy, A. (2014) On the Origin of the Human Mind. CreateSpace, North Charleston.

[22] Chung, D.Y. (2017) Human Cultural Evolution: Postmodernity as Rational Global Diversity. Open Journal of Social Sciences, 5, 304-337. https://doi.org/10.1016/S0047-2484(85)80005-1

[23] Pickford, M. and Senut, B. (2001) The Geological and Faunal Context of Late Miocene Hominin Remains from Lukeino, Kenya. Comptes Rendus Académie de la Terres et des Planètes, 332, 145-152.

[24] White, T., et al. (2009) Ardipithecus ramidus and the Paleobiology of Early Hominins. Science, 326, 75-86. https://doi.org/10.1126/science.1175802

[25] Carvalho, S., et al. (2012) Chimpanzee Carrying Behaviour and the Origins of Human Bipedality. Current Biology, 22, R180-R181.

https://doi.org/10.1016/j.cub.2012.01.052

[26] Lovejoy, C. (2009) Reexamining Human Origins in Light of Ardipithecus ramidus. Science, 326, 74-74e8.

[27] Chung, D.Y. (2018) Language Neuromechanics: The Human Biological-Language Evolution. Journal of Behavioral and Brain Science, 8, 447-472. https://doi.org/10.4236/jbbs.2018.88028

[28] Turner, J.C. and Reynolds, K.J. (2010) The Story of Social Identity. In: Postmes, T. and Branscombe, N., Eds., Rediscovering Social Identity: Core Sources, Psychology Press, New York, 13-32.

[29] Shultz, T., Hartshorn, M. and Kaznatcheev, A. (2009) Why Is Ethnocentrism More Common than Humanitarianism? Proceedings of the 31 st Annual Conference of the Cognitive Science Society, Amsterdam, 31 July-3 August 2013, 2100-2105.

[30] Hamlin, J.K., Mahajan, N. and Wynn, K. (2013) Not like Me = Bad Infants Prefer Those Who Harm Dissimilar Others. Psychological Science, 24, 589-594. https://doi.org/10.1177/0956797612457785

[31] Bellah, R. (2011) Religion in Human Evolution: From the Paleolithic to the Axial Age. Harvard University Press, Cambridge. https://doi.org/10.4159/harvard.9780674063099

[32] Chung, D.Y. (2018) The Eight Stages of Psychosocial Protective Development: Developmental Psychology. Journal of Behavioral and Brain Science, 8, 369-398. https://doi.org/10.4236/jbbs.2018.86024

[33] Taylor, M. (1999) Imaginary Companions and the Children Who Create Them. 
Oxford University Press, New York.

[34] Taylor, M., et al. (2004) The Characteristics and Correlates of Fantasy in School-Age Children: Imaginary Companions, Impersonation, and Social Understanding. Developmental Psychology, 40, 1173-1187. https://doi.org/10.1037/0012-1649.40.6.1173

[35] Simpkins, A. and Simpkins, C. (2016) Core Principles of Meditation for Therapy: Improving the Outcomes for Psychotherapeutic Treatments. John Wiley \& Sons, New York.

[36] Komjathy, L. (2014) Daoism: A Guide for the Perplexed. Bloomsbury Academic, New York.

[37] Calarge, C., Andreasen, N.C. and O’Leary, D.S. (2003) Visualizing How One Brain Understands Another: A PET Study of Theory of Mind. American Journal of Psychiatry, 160, 1954-1964. https://doi.org/10.1176/appi.ajp.160.11.1954

[38] Abraham, A. and Bubic, A. (2015) Semantic Memory as the Root of Imagination. Frontiers in Psychology, 6, 325. https://doi.org/10.3389/fpsyg.2015.00325

[39] Ferguson, M.A., et al. (2016) Reward, Salience, and Attentional Networks Are Activated by Religious Experience in Devout Mormons. Social Neuroscience, 13, 104-116. https://doi.org/10.1080/17470919.2016.1257437

[40] Boecker, H., et al. (2008) The Runner's High: Opioidergic Mechanisms in the Human Brain. Cerebral Cortex, 18, 2523-2531. https://doi.org/10.1093/cercor/bhn013

[41] Peoples, H., Duda, P. and Marlowe, F. (2016) Hunter-Gatherers and the Origins of Religion. Human Nature, 27, 261-282. https://doi.org/10.1007/s12110-016-9260-0

[42] Stringer, M. (1999) Rethinking Animism: Thoughts from the Infancy of Our Discipline. Journal of the Royal Anthropological Institute, 5, 541-556. https://doi.org/10.2307/2661147

[43] Graham, H. (2006) Animism: Respecting the Living World. Columbia University Press, New York.

[44] Dixson, A. and Dixson, B. (2011) Venus Figurines of the European Paleolithic: Symbols of Fertility or Attractiveness? Journal of Anthropology, 2011, Article ID: 569120. https://doi.org/10.1155/2011/569120

[45] Lewis-Williams, D. (2002) The Mind in the Cave: Consciousness and the Origins of Art. Thames \& Hudson, London.

[46] Berger, L., et al. (2015) Homo naledi, a New Species of the Genus Homo from the Dinaledi Chamber, South Africa. eLife, 4, e09560.

https://doi.org/10.7554/eLife.09560

[47] Dirks, P., et al. (2017) The Age of Homo naledi and Associated Sediments in the Rising Star Cave, South Africa. eLife, 6, e24231. https://doi.org/10.7554/eLife.24231

[48] Hoppál, M. (1987) Shamanism: An Archaic and/or Recent System of Beliefs. Theosophical Publishing House, Wheaton.

[49] Winkelman, M. (1990) Shamans and Other "Magico-Religious" Healers: A Cross-Cultural Study of Their Origins, Nature, and Social Transformations. Ethos, 18, 308-352. https://doi.org/10.1525/eth.1990.18.3.02a00040

[50] Gerdner, L. and Xiong, S. (2015) Demystifying Hmong Shamanism: Practice and Use. Bauu Institute, Boulder.

[51] Peoples, H. and Marlowe, F. (2012) Subsistence and the Evolution of Religion. Human Nature, 23, 253-269. https://doi.org/10.1007/s12110-012-9148-6

[52] Berbesque, J., Marlowe, F., Shaw, P. and Thompson, P. (2014) Hunter-Gatherers 
Have Less Famine than Agriculturalists. Biology Letters, 10, Article ID: 20130853. https://doi.org/10.1098/rsbl.2013.0853

[53] Wells, S. (2011) Pandora's Seed: Why the Hunter-Gatherer Holds the Key to Our Survival. Random House, New York.

[54] Goodman, A. and Armelagos, G. (1985) Disease and Death at Dr. Dickson's Mounds. Natural History Magazine, 94, 12-18.

[55] Ferguson, R. (2000) The Causes and Origins of Primitive Warfare. Anthropological Quarterly, 73, 159-164. https://doi.org/10.1353/anq.2000.0004

[56] Marlowe, F. (2010) The Hadza: Hunter-Gatherers of Tanzania. University of California Press, Berkeley.

[57] Woodburn, J. (1997) Indigenous Discrimination: The Ideological Basis for Local Discrimination against Hunter-Gatherer Minorities in Sub-Saharan Africa. Ethnic and Racial Studies, 20, 345-361. https://doi.org/10.1080/01419870.1997.9993965

[58] Steadman, L., Palmer, C. and Tilley, C. (1996) The Universality of Ancestor Worship. Ethnology, 35, 63-76. https://doi.org/10.2307/3774025

[59] Hofstede, G. (1997) Cultures and Organizations: Software of the Mind. McGraw-Hill, London.

[60] Swanson, G. (1960) The Birth of the Gods: The Origin of Primitive Belief. University of Michigan Press, Ann Arbor. https://doi.org/10.3998/mpub.6484

[61] Larraín, J. (2001) Identity and Modernity in Latin America. Blackwell Publishing, Malden.

[62] Aiello, L. and Dean, C. (1990) An Introduction to Human Evolutionary Anatomy. Academic Press, Cambridge.

[63] Zink, K. and Lieberman, D. (2016) Impact of Meat and Lower Palaeolithic Food Processing Techniques on Chewing in Humans. Nature, 531, 500-503. https://doi.org/10.1038/nature16990

[64] Hewes, G. (1973) Primate Communication and the Gestural Origin of Language. Current Anthropology, 14, 5-24. https://doi.org/10.1086/201401

[65] Cataldo, D., Migliano, A. and Vinicius, L. (2018) Speech, Stone Tool-Making and the Evolution of Language. PLoS ONE, 13, e0191071. https://doi.org/10.1371/journal.pone.0191071

[66] Indriati, E., et al. (2011) The Age of the 20 Meter Solo River Terrace, Java, Indonesia and the Survival of Homo erectus in Asia. PLOS ONE, 6, e21562. https://doi.org/10.1371/journal.pone.0021562

[67] Meister, C. (2009) Introducing Philosophy of Religion. Routledge, Abingdon, 10.

[68] Thomassen, B. (2010) Anthropology, Multiple Modernities and the Axial Age Debate. Anthropological Theory, 10, 321-342. https://doi.org/10.1177/1463499610386659

[69] Pew Research Center (2012) Religiously Unaffiliated. Pew Research Center, Washington DC.

http://www.pewforum.org/2012/12/18/global-religious-landscape-unaffiliated/

[70] Lyotard, J. (1984) The Postmodern Condition: A Report on Knowledge. Manchester University Press, Manchester.

[71] Duignan, B. (2018) Postmodernism, Britannica. https://www.britannica.com/topic/postmodernism-philosophy

[72] Featherstone, M. (1991) Consumer Culture and Postmodernism, Sage Publications, London. 
[73] De Botton, A. (2012) Religion for Atheists: A Non-Believer's Guide to the Uses of Religion. Hamish Hamilton, London.

[74] Hankey, W. (2017) Deconstructing Radical Orthodoxy. Routledge, London. 